JKKP: Jurnal Kesejahteraan Keluarga dan Pendidikan

http://doi.org/10.21009/JKKP

DOI: doi.org/10.21009/JKKP.022.04

E-ISSN: 2597-4521

\title{
Hubungan antara Pernikahan Usia Remaja Dengan Ketahanan Keluarga
}

\author{
Rahayu Puji Lestari \\ Program Studi Pendidikan Kesejahteraan Keluarga \\ Fakultas Teknik, Universitas Negeri J akarta \\ J In. Rawamangun Muka, J akarta Timur. 13220
}

\begin{abstract}
Abstrak
Penelitian bertujuan untuk mengetahui dan menganalisis hubungan antara pernikahan usia remaja dengan ketahanan keluarga. Penelitian dilakukan di wilayah Desa Lubang Buaya, Kecamatan Setu, Kabupaten Bekasi, Bekasi, selama bulan Juni 2015 hingga Juli 2015. Metode penelitian menggunakan metode survei dengan pendekatan kuantitatif korelasional. Populasi penelitian ini adalah pasangan suami/istri yang menikah pada usia remaja yaitu usia 12-21 tahun di wilayah Desa Lubang Buaya, Kecamatan Setu, Kabupaten Bekasi dan masih dalam ikatan pernikahan yang menikah pada bulan januari hingga bulan juni 2011. Sampel penelitian berjumlah 68 responden. Hasil uji normalitas data berdistribusi normal. Hasil uji hipotesis yaitu uji signifikasn koefisien kolerasi adalah signifikan. Koefisien korelasi dengan menggunakan rumus korelasional Lamda $(\lambda a)$ menghasilkan $=0,2$. Hasil hipotesis pada penelitian dan uji mengenai hubungan diperoleh bahwa terdapat hubungan antara pernikahan usia remaja dengan ketahanan keluarga di wilayah Desa Lubang Buaya, Kecamatan Setu, abupaten Bekasi. Koefisien determinasi yang diperoleh sebesar 4\%. Hasil ini menunjukkan bahwa pernikahan usia remaja $4 \%$ mempengaruhi hasil ketahanan keluarga. Kemudian sisanya $96 \%$ ditentukan oleh variabel lain.
\end{abstract}

Kata kunci: Pernikahan Usia Remaja, Ketahanan Keluarga

\section{Correlation Between Adolescent Marital And Family Resilience}

\begin{abstract}
The research aimed to know and to analyse adolescence and marriage relationship between the resilience of family. The research conducted in Lubang Buaya, Setu, Bekasi, on J une and J uly 2015. This research use quantitative correlational method. The population of this research is the wife/ husband who are married on 12-21 years old in Lubang Buaya Setu, Bekasi and still has been married J anuary-J une 2011. Sample research amounted to 68 respondents. Test result data to Gaussian normality. Test result linieritas is liner. The Hypothesis of testing is the significant test, the correlation coefficients is significant. A correlation coefficient with using formulas of correlational lamda $(\lambda a)$ is 0.2 .The results of the hypothesis to research and test it on the relationship obtained where is a relation between marriage adolescence with families strenghts in Lubang Buaya, Setu, Bek asi. The coefficient determination obtained by $4 \%$. The results show of one variable $(x)$ is the wedding early adolescence $4 \%$ to make influencing the outcome of one variable $(y)$ is the resilience of family. The remaining $96 \%$ determined by other.
\end{abstract}

The keywords: the marriage adolescence, family strenghts. 


\section{PENDAHULUAN}

Pada tahun 2010 berdasarkan data hasil sensus penduduk jumlah masyarakat Indonesia sebanyak 237,6 juta jiwa. Diantaranya sebesar 26,68 persen adalah remaja yang terdiri dari lakilaki sebanyak 50,70 persen dan perempuan 49,30 persen. Remaja berusia 10-14 tahun berjumah 22,7 juta dan remaja berusia 15-24 tahun berjumlah 40,57 juta. (BPS Hasil Sensus Penduduk 2010). Besarnya jumlah penduduk di Indonesia ini disebabkan karena laju pertumbuhan dan kelahiran yang tinggi yang disertai dengan meningkatnya jumlah pernikahan.

Pada tahun 2001 oleh United Nations Internasional Childern's Emergency F und (UNICEF), Indonesia merupakan 5 negara besar dengan persentase tertinggi didunia karena mencapai 34 persen dari usia 25-29 tahun yang menikah dibawah usia 18 tahun. Menurut United Nations Development E conomic and Social Affairs (UNDESA), Indonesia merupakan negara ke-37 dengan jumlah perkawinan dini terbanyak di dunia dan tertinggi kedua di ASEAN setelah Kamboja. Menurut data Susenas tahun 2009 menunjukan remaja di Indonesia usia 15-19 tahun yang berstatus kawin sebesar 6 persen (Wanita 5,4 persen dan pria 0,6 persen). Survei Demografi dan Kesehatan Indonesia (SDKI) tahun 2007 melaporkan bahwa dari 6,341 usia 15-19 tahun sebesar 12,8 persen dari mereka sudah menikah.

Riset Kesehatan Dasar (Rikesdas) tahun 2010, Perempuan muda di Indonesia yang menikah menurut umur pernikahan pertama paling tinggi sebanya 41,9 persen berusia 15-19 tahun sedangkan paling rendah sebanyak 0,6 persen berusia 35 tahun ke atas.

Undang-undang perkawinan meneybutkan bahwa batas minimal perkawinan seseorang adalah berusia 19 tahun untuk laki-laki dan 16 tahun untuk perempuan. Akan tetapi jika mengacu pada UU Perlindungan Anak No. 23 tahun 2002, perkawinan di usia 18 tahun ke bawah termasuk pernikahan dini.

Pilihan menikah di usia yang masih sangat dini bukanlah hal yang mudah untuk dihadapi dan dijalankan. Banyak resiko yang harus ditanggung oleh remaja itu sendiri, seperti akan terjadinya KDRT, resiko pada saat melahirkan karena belum maksimal kesiapan alat reproduksi, serta resiko kematian dari ibu atau bayi.

Keluarga yang terbentuk tanpa kematangan usia dan kesiapan dari segala arah, biasanya dari segi fisik tidak terpenuhi dengan baik karena belum mendapatkan pekerjaan yang baik dan ekonomi keluarganya tidak tercukupi. Dari segi psikologis yang belum memiliki kesiapan dalam membangun sebuah keluarga, menjadi seorang ibu, kemudian hamil dan menjalankan proses persalinan sehingga rentan terjadi kematian pada ibu dan bayi serta kelahiran premature. Dari segi sosial yang tidak bisa diterima oleh masyarakat karena pernikahan yang terjadi bisa disebabkan adanya kehamilan sebelum menikah atau married by accident.

Menurut ilmu kesehatan pasangan yang ideal menikah itu dari segi umur yang matang ialah antara umur 20-25 tahun bagi wanita dan umur 25-30 tahun bagi pria. Masa ini adalah masa yang paling baik untuk berumah tangga, karena pada usia itu baik pria maupun wanita sudah cukup matang dewasa. Dewasa dalam bertindak dan matang dalam berpikir. (Khairunnas, 2013: 26)

Bagi remaja yang menikah muda, proses penyesuaian diri tentunya lebih banyak seperti dalam hal menghadapi perubahan dirinya baik secara frisik, emosi dan sosial. Selain itu perubahan juga terjadi pada lingkungan keluarga, baik dari keluarga istri maupun keluarga dari pihak suami. Remaja yang mengalami pernikahan muda harus pula menyesuaikan diri terhadap peran baru yang dimilikinya yaitu sebagai seorang suami dan istri agar mempermudah bersosialisasi dalam lingkungannya baik lingkungan keluarga maupun masyarakat.

Pernikahan tanpa memiliki kesiapan dan pembekalan mengenai sebuah pernikahan dalam membangun rumah tangga memiliki banyak resiko sehingga ada beberapa pasangan yang bisa mempertahankan pernikahannya dan ada juga yang gagal dalam pernikahannya yang menyebabkan terjadinya perubahan status menjadi single parents. Pernikahan yang terjadi tanpa 
adanya kesiapan usia dan pembekalan pernikahan sebelum membentuk sebuah keluarga rentan terjadinya konflik antar anggota keluarga sedangkan untuk mempertahankan ketahanan keluarga membutuhkan proses di dalam sebuah keluarga. Seperti adanya saling keterbukaan antar pasangan, memiliki waktu yang banyak, saling berbagi, melakukan segala aktivitas bersama.

Kekuatan ini dapat menjadi landasan untuk pertumbuhan lanjutan dan perubahan positif dalam keluarga. Keluarga yang kuat memiliki waktu yang berkualitas dalam jumlah besar dan keluarga senang keluar bersama sebagai satu keluarga. Kebijakan pembangunan keluarga sejahtera menurut UU. No 10 Tahun 1992, diarahkan pada terwujudnya kualitas keluarga yang berdiri ketahanan keluarga dan kemandirian keluarga.

Banyak keluarga tidak dapat memenuhi kebutuhan mereka, baik secara fisik, psikologis dan social. Sehingga ketahanan keluarga tersebut dapat tergoyangkan dan tidak bisa membangun keluarga yang harmonis dan sejahtera. Pernikahan yang dilandasi dengan kematangan usia ketika memilih menikah dan sudah memiliki kesiapan secara lahir dan batin akan ada saja permasalahan-permasalahan yang tidak dapat terpecahkan. Bagaimana dengan mereka yang memilih menikah pada usia remaja. Padahal sekarang ini banyak keluarga-keluarga di Indonesia yang tingkat ketahanan keluarganya tidak dapat terpenuhi dengan baik sehingga tidak bisa membentuk keluarga yang harmonis dan sejahtera.

Hal ini banyak terjadi di Kecamatan Setu, Kabupaten Bekasi, Bekasi. Kecamatan setu yang terdiri dari beberapa desa dengan jumlah pernikahan usia dini yang tinggi. Sebanyak $45 \%$ luas wilayah Kecamatan Setu merupakan pemukiman yang didominasi permukiman perdesaan. Penduduk yang berada di Kecamatan Setu mayoritas bersuku sunda dan betawi dengan mata pencaharian sebagai petani, peternak dan berwirausaha, serta masih adanya perjodohan dan budaya turun temurun yaitu menikahkan anaknya di usia yang masih muda.

Kecamatan Setu terdiri dari 11 desa, dari 11 desa itu terdapat jumlah terbesar dalam data pernikahan usia dini yang diperoleh dari KUA Kecamatan Setu yaitu sebesar 82 orang yang bertempat tinggal di Desa Lubang Buaya. Berdasarkan latar belakang dan permasalahan yang ada pada, penulis bermaksud untuk melakukan penelitian dengan memfokuskan dengan judul penelitian "Hubungan Antara Pernikahan Usia Remaja dengan Ketahanan Keluarga"

\section{Pernikahan}

Dalam bahasa Indonesia perkawinan berasal dari kata "kawin" yang menunt bahasa artinya membentuk keluarga dengan lawan jenis, melakukan hubungan kelamin. Perkawinan disebut juga "pernikahan" yang berasal dari kata nikah yang menunut bahasa rtinya mengumpulkan, saling memasukkan, dan digunakan untuk arti bersetubuh (Ghozali, 2008: 7). Selain itu mufid juga menyatakan bahwa pernikahan yaitu akad antara calon pengantin pria dengan pihak calon pengantin wanita yang bukan muhrimnya (Mufid, 2002:43).

Menurut undang-undang Nomor 1 Tahun 1974 (Pasal 1), perkawinan itu ialah ikatan lahir dan batin antara seorang pria dan seorang wanita sebagai suami istri dengan tujuan membentuk keluarga (rumah tangga), yang bahagia dan kekal berdasarkan Ketuhanan Yang Maha Esa. Sedangkan menurut Hurlock (1992), perkawinan adalah suatu penyatuan jiwa da raga dua manusia berlawanan jenis dalam suatu ikatan yang suci dan mulia di bawah lindungan hukum dan Tuhan Yang Masa Esa

Menurut Bowner dan Spanier dalam Rahmi (2003) terdapat beberapa alasan seseorang untuk menikah seperti mendapatkan jaminan ekonomi, membentuk keluarga, mendapatkan keamanan emosi, harapan orang tua, melepaskandiri dari kesepian, menginginkan kebersamaan, mempunyai daya tarik seksual, untuk mendapatk an perlindungan, memperoleh posisi sosial dan prestise, dan karena cinta. Tujuan pernikahan untuk memenuhi tuntunan hajat tabiat kemanusiaan, berhubungan antara laki-laki dan perempuan dalam ikatan perkawinan untuk membentuk keluarga 
yang tenteram (sakinah), cinta kasih (mawaddah) dan penuh rahmat, agar dapat melahirkan keturunan yang sholeh dan berkualitas menuju terwujudnya rumah tangga bahagia.

\section{Remaja}

Remaja dalam arti adolescence (Inggris) memiliki makna tumbuh ke arah kematangan; kematangan disini tidak hanya berarti kematangan fisik, tetapi juga kematangan sosial-psikologis. Hal ini sangat berkaitan dengan kehidupan masyarakat di mana remaja tersebut tinggal. Pada masa ini sebenarnya tidak mempunyai tempat yang jelas karena tidak termasuk golongan anak tetapi tidak juga termasuk golongan dewasa atau tua. Papalia, Old dan Feldman menyatakan bahwa masa remaja dimulai dari pada usia 11 atau 12 sampai masa remaja akhir atau awal usia dua puluhan. (Papalia, et al. 2008 : 534). Sedangkan menurut Deswita rentang waktu usia remaja ini dibedakan atas tiga, yaitu 12-15 tahun = masa remaja awal, 15-18 tahun = masa remaja pertengahan, dan 18-21 tahun = masa remaja akhir. Remaja awal dan akhir inilah yang disebut masa antara anak-anak dan remaja (Deswita, 2006: 192). Marcia dalam Sprinthall dan Collins (2002) menyatakan bahwa pada umumnya penggolongan remaja dibagi menjadi tiga tingkatan, yaitu remaja awal (11-15 tahun), remaja menengah (16-18 tahun), dan remaja akhir (19-20 tahun). Sementara F.J. Monks berpendapat bahwa secara global masa remaja berlangsung antara 12-21 tahun, dengan pembagian 12-15 tahun: masa remaja awal, 15-18 tahun: masa remaja pertengahan, 18-21 tahun masa remaja akhir (Monsk, 2002).

Tahap perkembangan remaja dimulai dari fase remaja awal sampai dengan fase remaja akhir. Pada fase- fase ini terdapat beragam ciri khas pada masing-masing fase, di antaranya:

1) Fase Remaja Awal (early adolescence)

Pada fase ini ketertarikan pada lawan jenis mulai nampak. Sehingga, remaja mencari suatu pola untuk memuaskan dorongan genitalnya. Menurut Steinberg (dalam Santrock, 2002: 42) mengemukakan bahwa masa remaja awal adalah suatu periode ketika konflik dengan orang tua meningkat melampaui tingkat masa kanak-kanak. Sunaryo (2004: 56) berpendapat bahwa, hal terpenting pada fase ini, antara lain:

1. Tantangan utama adalah mengembangkan aktivitas hetero- seksual

2. Terjadi perubahan fisiologis

3. Terdapat pemisahan antara hubungan erotik yang sasarannya adalah lawan jenis dan keintiman dengan jenis kelamin yang sama

4. Jika erotik dan keintiman tidak dipisahkan, maka akan terjadi hubungan homoseksual

5. Timbul banyak konflik akibat kebutuhan kepuasan seksual, keamanan dan keakraban

6. Tugas perkembangan yang penting adalah belajar mandiri dan melakukan hubungan dengan jenis kelamin yang berbeda.

2) Fase Remaja Menengah (middle adolescence)

Pada tahap ini remaja cenderung lebih membutuhkan kawan-kawan. Ada kecenderungan narcistik yaitu mencintai diri sendiri, dengan menyukai teman- teman yang memiliki sifat yang sama dengan dirinya. Remaja pun sering mengalami kebingungan dalam menetukan sikapnya pada oranglain. Menurut Gunarsa (2001), ciri-ciri masa remaja tengah antara lain :

1. Mencari identitas diri

2. Timbulnya keinginan untuk kencan

3. Memiliki rasa cinta yang dalam

4. Mengembangkan kemampuan berpikir abstrak

5. Berkhayal tentang aktifitas seks

3) Fase Remaja Akhir (late adolescence)

Menurut Sunaryo (2004: 57) tugas perkembangan fase remaja akhir economically, intelectually, dan emotionally self sufficient. Sarwono (2008: 25) mengatakan bahwa tahap ini 
adalah masa konsolidasi menuju periode dewasa dan ditandai dengan pencapaian lima hal, yaitu;

1. Minat yang makin mantap terhadap fungsi-fungsi intelek

2. Egonya mencari kesempatan untuk bersatu dengan orang-orang lain dan dalam pengalamanpengalaman baru.

3. Terbentuk identitas seksual yang tidak akan berubah lagi

4. Terlalu memusatkan perhatian pada diri sendiri diganti dengan keseimbangan antara kepentingan diri sendiri dengan orang lain

5. Tumbuh "dinding" yang memisahk an diri pribadinya (private self) dan masyarakat umum (the public)

\section{Pernikahan Usia Remaja}

Pengertian pernikahan dini secara umum, pernikahan dini yaitu: merupakan instituisi agung untuk mengikat dua insan lawan jenis yang masih remaja dalam satu ikatan keluarga. Pengertian pernikahan dini tentunya tidak sebatas pengertian secara umum saja, tapi juga ada pengertian lain, pengertian pernikahan dini diantaranya: Pernikahan dini adalah sebuah nama yang lahir dari komitmen moral dan keilmuan yang sangat kuat, sebagai sebuah solusi alternative (Sarwono,1983). Artinya, pernikahandini bisa dilakukan sebagai solusi untuk menghindari penyimpangan- penyimpangan dikalangan remaja.

Pernikahan dini adalah pernikahan di bawah usia yang seharusnya belum siap untuk melaksanakan pernikahan (Nukman, 2009). Pernikahan dini atau kawin muda sendiri adalah pernikahan yang dilakukan oleh pasangan ataupun salah satu pasangannya masih dikategorikan remaja yang berusia dibawah 19 tahun (WHO, 2006). Sehingga seharusnya pernikahan dilakukan pada saat remaja sudah memasuki usia dewasa, karena ketidaksiapan dalam pernikahan berdampak pada kehidupan berumah tangga.

Ragamnya faktor yang mendorong terjadinya pernikahan di usia yang masih dini. Faktorfaktor yang mempengaruhi terjadinya perkawinan usia muda menurut Hollean dalam Suryono (2004), pernikahan usia muda terjadi karena :

1. Masalah ekonomi keluarga

2. Orangtua dari gadis meminta masyarakat kepada keluarga laki-laki apabila mau mengawinkan anak gadisnya

3. Bahwa dengan adanya perkawinan anak-anak tersebut, maka dalam keluarga gadis akan berkurang satu anggota keluarganya yang menjadi tanggung jawab (makanan, pendidikan, dan sebagainya)

\section{Hakikat Ketahanan Keluarga}

Menurut Sunarti (2001:9), ketahanan keluarga merupakan kemampuan keluarga untuk mengelola sumberdaya dan masalah yang dihadapi keluarga agar sejahtera yaitu terpenuhinya kebutuhan seluruh anggota keluarga. DeFrain (1999) merupakan kekuatan yang apabila diidentifikasi lebih lanjut, kekuatan ini dapat menjadi landasan untuk pertumbuhan lanjutan dan perubahan positif dalam keluarga.

Ketahanan keluarga dapat terlihat dari kondisi atau keadaan dalam keluarga itu sendiri. Komunikasi antar anggota keluarga, pemenuhan kebutuhan keluarga, kasih sayang antar anggota keluarga, dan kesehatan keluarga. Selain itu, ada juga komponen ketahanan keluarga menurut Chapman, Martinez et al. dan Sunarti, diantaranya:

Menurut Chapman (2000) ada lima tanda adanya ketahanan keluarga yang berfungsi dengan baik. Diantaranya : 
1. Sikap melayani sebagai tanda kemuliaan

2. Keakraban antara suami-istri menuju kualitas perkawinan yang baik

3. Orangtua yang mengajar dan melatih anaknya dengan penuh tantangan kreaktif, pelatihan yang konsisten dan mengembangkan keterampilan

4. Suami-istri yag menjadi pemimpin dengan penuh kasih

5. Anak-anak yang mentaati dan menghormati orangtuanya

Menurut Martinez et al. (2003), yang disebut dengan keluarga yang kuat dan sukses adalah dalam arti lain dari ketahanan keluarga adalah sebagai berikut (Puspitawati, 2013:3) :

1. Aspek kesehatan

2. Aspek ekonomi

3. Kehidupan keluarga yang sehat,

4. Aspek pendidikan

5. Aspek kehidupan bermasyarakat,

6. Menyikapi perbedaan dalam masyarakat melalui keterampilan interaksi personal dengan berbagai budaya.

Menurut Sunarti (2010: 9) menyatakan bahwa komponen ketahanan keluarga dapat dilihat berdasarkan dua pendekatan, yaitu :

1. Komponen Laten

a. Ketahanan Fisik: Ketahanan fisik berkaitan dengan kemampuan ekonomi keluarga, yaitu kemampuan anggota keluargadalam memperoleh sumberdaya ekonomi dari luar sistem untuk memenuhi kebutuhan dasar seperti pangan, sandang, perumahan, pendidikan dan kesehatan

b. Ketahanan Sosial: Ketahanan sosial terdiri dari sumber daya nonfisik, mekanisme penanggulangan masalah yang baik, berorientasi terhadap nilai-nilai agama, eektif dalam berkomunikasi, senantiasa memelihara dan meningkatkan komitmen keluarga, memelihara hubungan sosial, serta memiliki penanggulangan kritis.

c. Ketahanan Psikologis: Ketahanan psikologis merupakan kemampuan anggota keluarga untuk mengelola emosinya sehingga menghasilkan konsep diri yang positif dan kepuasaan terhadap pemenuhan kebutuhan dan pencapaian tugas perkembangan keluarga.

2. Pendekatan Sistem

a. Input: Sumberdaya keluarga, termasuk nilai dan tujuan yang melandasinya

b. Proses: Manajemen sumber daya keluarga, masalah yang dihadapi dan penanggulangan masalah keluarga

c. Output: Kesejahteraan keluarga (secara fisik, sosial, psikologis, atau kesejahteraan subjektif dan kesejahteraan objektif)

Tipologi keluarga merupakan bagian dalam pengelolaan stress keluarga. Keluarga dengan tipologi yang baik diasumsikan dapat mengelola sumber stress sehingga tidak menyebabkan distress. Oleh karena itu, tipologi keluarga dengan menejemen stress keluarga sangat berkaitan. Kedua unsur ini juga dapat mengukur tinggi rendahnya ketahanan keluarga. Menurut Sunarti (2013: 36) menjelaskan indikator tipologi keluaga, diantaranya:

1. Ketangguhan Keluarga ( $F$ amily hardiness): kekuatan dan ketahanan keluarga yang timbul oleh perasaan yang kuat sebagai suatu keluarga dalam mengontrol peristiwa serta kesulitankesulitan hidup, memandang kehidupan begitu berarti, mengutamakan keterlibatan dalam aktivitas keluarga, dan memiliki komitmen untuk belajar, mengeksplorasi hal dan tantangan baru serta pengalaman-pengalaman baru;

2. Pertalian Keluarga (family coherence): penerimaan keluarga terhadap tekanan yang menimpa, loyalitas, kebanggan, keyakinan, kepercayaan, kehormatan, perhatian, dan berbagai nilai 
dalam kondisi keluarga yang tegang;

3. Kelekatan Emosi Keluarga (family bonding): derajat yang mengukur kelekatan emosi dan kebersamaan keluarga serta intensitas antar anggota keluarga;

4. Keluwesan Keluarga (family flexibility): kemampuan keluarga untuk merubah aturan, batasan, dan peran untuk mengakomondasikan atau mengatur tekanan perubahan dari dalam maupun luar keluarga.

\section{METODE PE NE LITIAN}

Jenis penelitian yang digunakan adalah kuantitatif, penelitian kuantitatif merupakan sarana untuk menguji teori objektif dengan memeriksa hubungan antara variabel (Puspitawati dan Herawati, 2013: 223). Dengan metode yang digunakan di dalam penelitian ini adalah survei dengan pendekatan korelasional. Dalam penelitian ini menggunakan angket dan lembar observasi.

Dengan rumus sampel di dapatkan 68,04 orang responden lalu akan dibulatkan menjadi 68 orang responden. Instrument yang digunakan dalam penelitian ini berupa angket atau kuesioner yang terdiri dari dua bagian yaitu pernikahan usia dini dan ketahanan remaja. Teknik kuesioner atau angket adalah suatu pengumpulan data dengan memberikan dan menyebarkan daftar pertanyaan kepada responden dengan harapan memberikan respon atas daftar pertanyaan tersebut (Puspitawati dan Herawati, 2013: 206).

\section{HASIL DAN PEMBAHASAN}

Uji hipotesis statistik pada korelasional Lamda ( $\square$ a) diperoleh hasil 0,2 yang berarti rendah. Uji signifikan koefisien kolerasi pada penelitian ini memperoleh hasil $\square^{2 \text { hitung }}=1,133$ dan $\square^{2}$ tabel = 1 yang berarti ada hubungan yang signifikan antara variabel $X$ dan variabel $Y$, sedangkan untuk memperoleh angka dari perhitungan koefisien determinasi adalah $4 \%$. Hasil ini menunjukkan bahwa variabel $(X)$ yaitu pernikahan usia remaja $4 \%$ mempengaruhi hasil dari variabel $(Y)$ yaitu ketahanan keluarga. Kemudian sisanya $96 \%$ ditentukan oleh hal lain.

Presentase pada ketahanan keluarga dengan usia remaja yang hitung berdasarkan dimensi sehingga dihasilkan presentase terbesar pada dimensi keluarga tumbuh dan berkembang yaitu sebesar $80 \%$ pada remaja akhir dan terendah yaitu $76,30 \%$ pada remaja awal. Hal ini disebabkan karena remaja akhir memiliki ketangguhan keluarga dan pertalian keluarga yang kuat, dimana remaja yang menikah pada masa akhir ini sudah dapat membedakan mana yang harus didahulukan serta sudah lebih bisa membagi waktu dengan keluarga barunya. Selain itu juga dapat mengatasi permasalahan didalam sebuah keluarga ketika keluarga sedang di hadapi sebuah permasalahan dan konflik. Berbeda dengan remaja awal yang masih tergantung dengan orang tua dan masih belum bisa mengatasi permasalahannya sendiri.

Presentase pada ketahanan keluarga dengan usia remaja yang hitung berdasarkan dimensi sehingga dihasilkan presentase terbesar pada dimensi keluarga lenting yaitu sebesar $78,80 \%$ pada remaja awal dan terendah yaitu $76,30 \%$ pada remaja akhir. Hal ini disebabkan karena remaja awal masih memliki kelekatan emosi yang kuat dengan orang tua dan anggota keluarga lainnya serta masih belum bisa untuk mengatur ada nya tekanan perubahan dari dalam maupun luar keluarga berbeda dengan remaja akhir yang sudah mulai bisa mandiri.

Dari kedua dimensi tersebut yang menjadi acuan untuk mengukur ketahanan keluarga disimpulkan bahwa ketahanan keluarga yang lebih tinggi atau kuat pada pernikahan yang dilakukan oleh remaja menengah karena adanya waktu kebersamaan antar anggota keluarga untuk melakukan diskusi, bercerita dan melakukan aktivitas tertentu secara bersamaan, selain itu memiliki prinsip dalam menghadapi sebuah permasalahan sehingga dapat memilih untuk membuat 
keputusan dan mencari jalan keluar, adanya rasa saling percaya antar anggota keluarga satu sama lain, serta mendapat dorongan dan dukungan yang kuat dari anggota keluarga lain hal ini didukung berdasarkan hasil penelitian bahwa $49 \%$ pasangan remaja bertempat tinggal bersama orangtuanya.

\section{KESIMPULAN}

Berdasarkan pengolahan data deskriptif, pengolahan data statistik dan hasil analisis data yang telah dilakukan, maka dapat ditarik kesimpulan bahwa dari hasil penelitian dari 68 responden yang menyatakan bahwa ada hubungan yang signifikan antara variabel $X$ dan variabel $Y$, selain itu pernikahan usia remaja memengaruhi sebesar $4 \%$ terhadap ketahanan keluarga dan $96 \%$ di pengaruhi oleh hal lain. Ketahanan keluaga pada pasangan yang menikah di remaja menengah memiliki ketahanan keluarga yang paling tinggi dibandingkan ketahanan keluarga yang menikah ketika berada pada masa remaja awal dan akhir

\section{DAFTAR PUSTAKA}

Akdon dan Hadi, S. 2005. Aplik asi Statistika dan Metode Penelitian untuk Administrasi dan Manajemen. Bandung: Dewa Ruchi

Arikunto, S. 2002. Prosedur Penelitian Suatu Pendek atan Praktek. Jakarta: Rineka Cipta.

Arikunto, S. 2006. Prosedur P enelitian S uatu Pendek atan P rak tik. Jakarta: Rineka Cipta.

Budiyono. 2003. Metodelogi Penelitian Pendidik an. Surakarta: Sebelas Maret University Press.

Deswita, 2006. Psikologi Perkembangan. Bandung: Remaja Rosdakarya.

Djaali dan Muljono, P. 2008. Penguk uran Dalam Bidang Pendidik an. Jakarta: Grasindo.

F.J. Monks, dkk. 2002. Psikologi Perkembangan. Yogyakarta: Gadjah Mada University Press.

Ghozali, A. R. 2008. Perkawinan hukum islam. Jakarta: Kencana

hasan, I. 2004. Anaisis Data Penelitian dengan Statistik. Jakarta: Bumi Aksara

Ihsan. 2008. Tuntunan Praktis Rumah Tangga Bahagia. Surabaya: BP-4 Jatim.

Khairunnas. 2013. Menyiapk an Generasi Emas. Jakarta: BKKBN.

Papalia, D. E., Ols, S.W., Feldman, R.D., 2008. Psikologi Perkembangan edisi kesembilan. Jakarta: Kencana Prenada Media Group.

Puspitawati, H dan Herawati, T. 2013. Metodelogi Penelitian Keluarga. Bogor: IPB Press.

Riduwan dan Akdon. 2005. Rumus dan Data dalam Analis is Statistik a. Jakarta: Alfabeta.

Sarwono, S. 2008. Psikologi Remaja. Jakarta: Rajawali Pers

Siregar, S. 2013. Statistik parametik Untuk Penelitian Kuantitatif. Jakarta: bumi aksara

Sudijono, A. 2011. Pengantar Statistik Pendidik an. Jakarta: PT. Grafindo Persada.

Sudjana. 2005. Metoda Statistika. Bandung: Penerbit Tarsito

Sugiyono. 2005. Metode Penelitian Kualitatif. Bandung: CV. Alfabeta.

Sugiyono. 2012. Metode Penelitian Pendidikan Pendek atan Kuantitatif kualitatatif dan R.D. Bandung: Alfabeta.

Sugiyono. 2008. Metode Penelitian Kuantitatif Kualitatif dan R\&D. Bandung: CV. Alfabeta.

Sukmadinata, N. S. 2011. Metode Penelitian Pendidik an. Bandung: Alfabeta.

Sunarti, E. 2013. Ketahanan Keluarga. Bogor: IPB Press.

Sunaryo, 2004. Psikologi untuk keperawatan. Jakarta: EGC.

Suntrock, 2003. Perkembangan remaja. Jakarta: Erlangga.

Suryani, E \& Widyasih, H. 2012. Psikologi ibu dan anak. Yogyakarta : Fitramaya.

Usman, H dan Akbar, P. S. 2008. Pengantar Statistika. Jakarta: Bumi Aksara. 